\title{
CRISIS COMMUNICATION IN THE TIME OF COVID-19: The Significance of Grassroot Initiative in Democratic Countries (Case of Brazil, Indonesia, and the United States)
}

\author{
Marshell Adi Putra, Ign. L. Adhi Bhaskara, Anggia Valerisha \\ Department of International Relations \\ Universitas Katolik Parahyangan, Bandung, Indonesia \\ Corresponding Author Email: marshell.ap@unpar.ac.id
}

\begin{abstract}
All countries are adapting to the dynamics and changes posed by the global pandemic of COVID-I9. The government is expected to act immediately and effectively in response to the crisis, particularly through public communication to their respective citizens. In this regard, crisis communication is vital to minimize the loss and damage caused by the pandemic in various aspects of life. Being able to communicate in the right and effective way during a crisis can determine the overall outcome of the situation. This paper explores on how crisis communication has conducted in the time of COVID-I9 by comparing three respective democratic governments: Brazil, Indonesia, and the United States. Through qualitative method, this paper argues that in a democratic society where openness and freedom of speech is guaranteed, the process to disseminate information through crisis communication could be a daunting task. The study indicated at least four main factors that could hinder the effectiveness of crisis communication: I) a large population and politically divide in the society; 2) the lack of coordination between levels of governments; 3) the governments' lack of capability to communicate with the public; and 4) an incompetent crisis communication strategy. The study also found some of the grassroot initiative which is seen significance to fill the information gaps left by the government.
\end{abstract}

Keywords: COVID-I9; crisis communication; democracy; grassroot initiative; pandemic; open government data intermediary

\begin{abstract}
Abstrak
Semua negara beradaptasi dengan dinamika dan perubahan yang terjadi selama pandemi COVID-I9. Pemerintah diharapkan dapat bertindak cepat dan efektif dalam merespon krisis, khususnya dalam melakukan komunikasi publik kepada masyarakat. Berkaitan dengan hal ini, komunikasi krisis sangat penting untuk meminimalkan kerugian dan kerusakan akibat pandemi di berbagai aspek kehidupan. Mampu berkomunikasi dengan cara yang benar dan efektif selama krisis dapat menentukan keseluruhan hasil dari penanganan situasi. Tulisan ini mengeksplorasi bagaimana komunikasi krisis dilakukan di masa COVID-I9 dengan membandingkan tiga pemerintahan demokratis: Brazil, Indonesia, dan Amerika Serikat. Melalui pendekatan metode kualitatif, tulisan ini berpendapat bahwa dalam masyarakat demokratis di mana keterbukaan dan kebebasan berbicara dijamin, proses penyebaran informasi melalui komunikasi krisis bisa menjadi tugas yang berat. Studi ini mengindikasikan setidaknya empat faktor utama yang dapat menjadi rintangan dari efektivitas komunikasi krisis, , diantaranya: I) populasi yang besar
\end{abstract}


dan kesenjangan politik yang ada di masyarakat, 2) kurangnya koordinasi di antara berbagai tingkatan pemerintahan, 3) kurangnya kapabilitas pemerintah dalam berkomunikasi dengan publik, dan 4) strategi komunikasi krisis yang inkompeten. Lebih lanjut, hasil studi menunjukkan adanya beberapa upaya inisiatif dari akar rumput yang dilihat signifikan dalam mengisi kesenjangan informasi yang disampaikan pemerintah.

Kata Kunci: COVID-Ig; komunikasi krisis; demokrasi;, inisiatif akar rumput; pandemi; open government data intermediary

\section{INTRODUCTION}

COVID-I9 pandemic has tested the resilience of humans as well as the country in overcoming the crisis. Not only threat to health issues as its main focus, but also the aspect of social and economic are becoming two major challenges that are seriously affected. This situation has become the threat to the security of human being as well as states and global security. It has also posed a new problems and challenges especially regarding how the states or governments act immediately and effectively to prevent or even to stop the spread of the virus. All are adapting to the changes that occur during the pandemic of COVID-I9 where most of the government in early terms, implemented the social vaccine strategy covering social restriction policies and lockdown in response to the crisis (Valerisha \& Putra, 2020).

In dealing with a pandemic, the public health aspect is not the only thing that needs to be addressed. In March 2020, in an interview with $\mathrm{CNBC}$, Singapore's Foreign Minister Vivian Balakrishnan said that the COVID-I9 pandemic is a test for every country's quality of healthcare, standard of governance and social capital. In addition, he emphasizes that all of those qualities should be viewed as a tripod where "if any one of this tripod is weak, it will be exposed and exposed quite unmercifully by this epidemic." Realizing the importance of governance standard and social capital, the collaboration between the government and the public becoming more important than ever for democratic countries to deal with the pandemic situation.

While the problem of healthcare quality cannot be resolved in a short-term period, one of the most important aspect for the government can do during the crisis is to deliver a clear and transparent public communication to the respective citizens. In fact, the actual, accurate, and transparent information and data will encourage community to intended actions particularly to reduce the risk and the spread of the virus. Moreover, it will further produce the right policy or decision to end the pandemic. Crisis communication, in this regard, is vital to minimize the loss and damage caused by the pandemic in various aspects of life. In terms of crisis management, its effectiveness cannot occur without the quality of communication. Therefore, when the government is able to communicate well during a crisis can determine the overall outcome of the pandemic situation.

However, in a democratic society where freedom of speech is guaranteed, sending an effective message through crisis communication can be a challenge as well. With many advances of information and communication technology that exist today, the government is equipped with the ease in conveying information and message to the public. On the other hand, the government is also required to not only collect and process data related to public health, but also to deliver information that needs to be communicated for the public. Unfortunately, the public in some democratic countries such as Brazil, Indonesia, and the United States are increasingly doubting its government in handling the pandemic due to the poor public communication and data utilization.

In Brazil, President Bolsonaro is facing public distrust with the way he is perceiving the COVID-I9 situation. On many occasions, he continues to downplay how serious the situation is. To note some, in March last year, he said that COVID-I9 is a 'fantasy' and a 'media-created hysteria' (BBC, 2020). In November 2020 , when the death toll of COVID-I9 surpassed 162,000 he told his citizen to stop being 'sissies' and said "All of us are going to 
die one day." (Farzan \& Berger, 2020). By January 3I, 202I the case in Brazil has reached $8,996,876$ with the death toll of 220,I6I and placed them at second place among all countries (WHO, 2020).

A similar situation happened during the President Trump leadership in the United States. The Cornell Alliance for Science on its study stated that President Trump is the largest single component of 'infodemic' (Evanega, Lynas, Adams, \& and Smolenyak, 2020). With his way of communication, he managed to spread misinformation related to the pandemic and made a wider division among its citizen by politicizing the crisis (Hatcher, 2020). Until January 29, 202I the United States has recorded 25,354,044 cases with the death toll of 425,670 , making them as a country with the most cases and deaths in the world (WHO, 2020).

Indonesia, with the total number of I,037,993 cases and the death toll of 29,33I as per World Health Organization (WHO) Data January 29, 202I also dealing with some degree of public distrust towards its government. A survey conducted by Litbang Kompas found that as many as $52.5 \%$ of respondent was not satisfied by President Jokowi's performance, one year after its second term leadership (Halim, 2020). Aside from the fact that Indonesia has gained first place in terms of total cases and deaths in Southeast Asia, the numbers of distrust among the citizen also fueled by the lack of government decisiveness in dealing with the pandemic. It can be seen from how the government seems to prioritized economy over public health issue, it reflected when the President gave a green light for the constitution of Indonesia's Omnibus Law on Job Creation. On another occasion, the Coordinating Economic Minister said that the December 2020 local election is good for the circulation of the country's economy (Kusuma, 2020).

Before the COVID-I9, the last time the world faced a pandemic that had taken massive casualties was when the Spanish Flu hit the world in the period of I9I8-I920. Originated in Spain, the Flu had taken the lives of around 50 million people around the world during this period (Rosenwald, 202I). It was not only the first event of medical and isolation, but also posed social impact. The society, particularly in the United States at that time, has clear roles in engaging and participating to end the pandemic (Stern et.al, 20Io). For example, the success of social distancing, quarantine measures supported by the public in the United States (Navarro \& Markel, 20I6), and the close of the ports in Australia managed to repress the Spanish Flu spread in I9I8 (Riley, 2020). Since then, the world has also had to deal with several kinds of pandemics, including Severe Acute Respiratory Syndrome (SARS) and $\mathrm{HINI}$, although the speed at which those pandemics spread and their impact seem trivial compared to those of COVID-I9 and the Spanish Flu. From those series of unfortunate events, we believe that society's response to a pandemic is a crucial element in determining the success of handling a pandemic.

Based on the 2009's HiNi case study, researchers have suggested that low public trust could hinder the handling of a pandemic, and a good crisis communication strategy centered on transparency may provide a positive result (Feufel et al., 20Io). In democratic settings, most laypeople must reach their conclusions when responding to the crisis happening in their societies, and they often must rely on others in making judgments. Hence, trust becomes the utmost important factor for people to decide on an issue when they lack knowledge on it (Siegrist \& Cvetkovich, 2000). On the other hand, scholars have argued that public compliance toward health experts' recommendations during a pandemic is one of the critical factors determining the success of risk management strategies in which trust plays a crucial role (Siegrist \& Zingg, 2014).

We argue that the United States of America (US), Brazil, and Indonesia have something in common within this context: they are all democratic countries, and they are considered to have not done enough in handling the COVID-I9 pandemic. We argue that one of the prominent characteristics which can be identified from those countries' situations is the lack of a competent crisis communication strategy with transparency as its center. As a result, there is no public trust toward recommendations made by health experts. 
Furthermore, while scholars have argued that "democracy is beneficial for public health," pandemic, however, is a particular case (Kavanagh \& Singh, 2020, p. IOOI).

Some factors may cause the implementation of democratic values in a pandemic is not as beneficial as in other public health cases, particularly in terms of accountability mechanisms. In this case, it is the political economy interests and dynamics. For example, with the government's fast response and stringent measures, Singapore comes out as one of the countries in the world that many have acknowledged its success in handling the pandemic (Kuguyo et al., 2020). Meanwhile, in China, scholars highlights speedy response of the government and superb collective action as some of the key determinants of successful pandemic handling (Altakarli, 2020). Although it is seen as aggressive, China has shown a more effective public health policy alongside with the top-down crisis communication in response to the COVID-I9. The early responses and measures, large-scale of surveillance, preparation of medical facilities and supplies, along with new high technology tracking systems (Ibid, 2020). As a result, we could see a visible contrast in the result of pandemic handling between some democratic countries and countries with some authoritarian characteristics, such as China and Singapore.

Undeniably, the political economy interests and dynamics could also become a crucial factor determining pandemic handling in countries with some authoritarian characteristics. However, the USA, Brazil, and Indonesia leaders have one commonality that other democratic countries and countries with authoritarian characteristics may not have: the practice of populism by the leaders of those countries. Research has found some indications that populist attitudes negatively correlate with trust, and one of the effective ways to counter such a situation is by implementing a good and clear communication strategy (Eberl et al., 2020).

Based on the explanation above, this paper aims to explore how crisis communication is conducted in the time of COVID-I9 by comparing the three respective democratic gov- ernments which cover Brazil, Indonesia, and the United States.

\section{LITERATURE REVIEW}

The success and downfall stories of democratic institutions in handling a pandemic have been widely discussed. Some scholars have exemplified that in some countries with authoritarian features, the COVID-I9 pandemic handling seems to be working out quite well compared to democratic countries with a huge population (Kavanagh \& Singh, 2020) e.g. like in China's case.

In China, the total confirmed COVID-I9 cases from January 3, 2020, to June 3, 202I, were II2,458 cases with 4,995 deaths (WHO, 2020). Meanwhile, Singapore has total confirmed COVID-I9 cases of 62,100 cases with 33 deaths during the same period. On the contrary, the total confirmed COVID-I9 cases in the USA were $32,963,318$ cases with 589,555 deaths during the same period. Further, in the $\mathrm{UK}$, the total confirmed cases during the same period were 4,494,703 with I27,794 deaths.

Nevertheless, several democratic countries also show some promising results. South Korea, for example, has managed to dampen the spread of the COVID-I9. Scholars have argued that a combination of multiple strategies including transparency in communication strategy, health preparedness, and strong penalties or enforcement, is ones of the decisive factors that provide an acceptable result of a pandemic handling for South Korea (Her, 2020). Furthermore, an initial study also suggests that there is no significant difference in stringent measures to fight against COVID-I9 between countries with autocratic characteristics and democratic countries (Annaka, 202I).

The discussion about crisis communication during the COVID-I9 pandemic has also been discussed among scholars. A study conducted by Jong (202I) proposed an assessment tool to evaluate the performance of crisis communication during COVID-I9 and other pandemics. The tool which is called the Assessment tool for Crisis Communication during Pandemics (ACCP) cover six domains, 
which are: I) Sense making in times of crisis, II) Public leadership in time, III) Public health professionals and expert voices, IV) Interaction with stakeholders, V) Instructions to the public, and VI) Story telling. This tool allows academics to conduct an assessment through interview session to who actively involved in crisis communication management, by comparing the practice of crisis communication of the countries during a pandemic without negating the context they have, such as cultural traits, political regimes, and features of the media (Jong, 202I; Cheng \& Lee, 2019).

Moreover, in a pandemic situation and its relation to democracy, the use of public health data by its government and citizen is crucial. Obtaining accurate and transparent data is something that the government needs to do seriously. Apart from that, the government also needs to do well with its crisis communication. Public trust then becomes an important goal to be achieved especially for a democratic government. This is definitely not an easy matter for a democratic government to do it by itself. In some situations, citizens often distrust their government and must organize some grassroots activism to fill in the gap which cannot be fulfilled by the government.

One of the roles that can be done by the citizens to fill in the gap left by the government is to become the open government data intermediaries. Open government data intermediary has a role to retrieve, process, translate, or disseminate information from the data obtained from the government (Magalhaes, Roseira, \& Strover, 2013). In doing their role as the open government data intermediaries, grassroots communities can be categorized into three types: activists, journalists, and hackers (Schrock \& Shaffer, 20I7). Each of the types has different norms, for activists they have a political goal to get citizen more active and engaged. For journalists, they can give a pressure for government to do a reformation. As for hackers, they are able to help solve citizen's problem with their data and software literacies.

In another study conducted between 20I4-20I7, data activism performed by the community could help and pressure the gov- ernment to formulate better policies and be able to build public trust. From this study, there are at least four processes that can be studied: counter-data action, resource mobilization, development of critical consciousness, role of media and design. From the case study that was used in this study, this process of data activism can drive the transformation of grassroots capacity building (Meng \& DiSalvo, 20I8).

\section{RESEARCH METHODS}

The study employed qualitative methods which was comparative approach to explore the practices of crisis communication of three respective countries (or governments) of Brazil, Indonesia, and the United States. Through comparative study, this paper tries to seek and clarify whether certain behavior patterns are part of characteristics for a certain group or certain culture (Knoll, I979). Moreover, Sartori (I99I) stated that the comparison of particular studies is needed in order to control the observed units of variation that make up the theoretical relationship. The countries of Brazil, Indonesia and the United States of America (US), were chosen because they have something in common: democratic countries which become the primary factor in this study, and huge population with some indications of greater political division. Moreover, the data was collected through documentation studies such as books, journals, reports, websites, speeches, and news. The study limited the data from January 2020 to January 202I.

\section{RESULT AND DISCUSSION}

The discussion is divided into three parts. The first discusses the political economy interests and dynamics of the three countries. Second, the comparison of timeline of crisis communication of the three respective governments. Third, the public efforts in responding the governments' crisis communication which later defined as grassroot initiative. 


\section{The Political Economy Interests and Dynamics of Brazil, Indonesia, and the US}

When the first COVID-I9 case hit the US on January 20, 2020, the US government under President Donald Trump's administration was unconcerned. In an interview with a national news channel, Trump first response was he tried to undermine the crisis by saying that the US government had total control over the situation as it only a case of a person who traveled from China (Eugene Kiely; Lori Robertson; Rem Rieder; D’Angelo Gore, 2020). Since then, his stance on the COVID-I9 pandemic has been relatively consistent. Scholars have argued that most of the time, Trump has been downplaying the significance of the pandemic and the risk it may follow (Yamey \& Gonsalves, 2020). We argue that Trump is also using similar rhetoric to save his presidential seat and interests during the COVID-I9 pandemic.

Trump was elected as the US President in a tight battle with Hillary Clinton in 2016. Even though Hillary managed to win the popular vote by around two percent of advantage, Trump eventually won the presidential election after secured 306 electoral votes compared to 232 votes obtained by Hillary (The New York Times, 20I7). From the start to the finish of his term, Trump has always been sitting on the edge (Akhli \& Samhudi, 2020). Trump's approval rating by Gallup shows that it only managed to reach 49 points during the 20I7-2020 period (Gallup, 202I).

The US itself has been politically more divided than ever during Trump's tenure. His political opponents, who mainly come from the Democratic Party, are always in a position to bring Trump's down off his presidential seat. The impeachment initiative was one of many examples of the efforts. To gain an advantage, a social scientist has argued that Trump had enabled populism as his strategy to gain loyal support from his supporters (Rowland, 20I9). Using populism rhetoric, Trump tried to create a nuance in which there was a possibility that his supporters may lose their country, either it is from external or internal threats. We suggest that Trump's strategy to blame China for spreading the COVID-I9 virus is one example of how he creates such nuance using populism rhetoric. Another example, most of Trump's comments regarding the COVID-I9 pandemic were using pro-people and anti-elite nuance. In this regard, Trump chooses to support anti-lockdown protesters, for example, instead of making a clear communication strategy based on proven medical sciences (BBC, 2020; Sevastopulo \& Shubber, 2020). He played the economic crisis card that people need to continue with their lives as the economic downturn hit them hard. Trump did this even though previously, Trump and his administration had issued a recommendation to gradually ease restrictions, including social distancing policy, contact tracing, and testing.

Furthermore, some official statements issued by the officials, including Trump himself, have created confusion within the society. For example, in April 2020, Trump rejected his own administration's advice to wear masks (Smith, 2020). The Centers for Disease Control and Prevention (CDC) advise people in the US to wear non-medical cloth face covering, but Trump said he would not do it. The situation may indicate a lack of coordination within Trump's administration at a certain level.

In Brazil, the situation is not much different. Under President Jair Bolsonaro's administration, the Brazilian government also did not do well against COVID-I9 as the number of COVID-I9 cases and death tolls continue to rise. The study indicates the problem of leadership capability and lack of coordination within the government of Brazil. It has been known that the lack of leadership capability and coordination is often regarded as the center of calamity. So far, Brazil has had four health ministers since pandemic began. Furthermore, under Bolsonaro's leadership, one foreign minister, all military generals, and four other cabinet members has left. This political crisis has led to a lack of coordination within the Brazilian government as well as mishandling of foreign relations that resulted in a lack of vaccines supply (BBC, 202I).

Moreover, Bolsonaro implements quite a similar strategy as Trump as he highlighted the importance of the economy (Lasco, 2020). He also downplayed the impact of the COVID-I9 on public health. There is an indi- 
cation that Bolsonaro chooses the strategy to escape from his responsibility fixing Brazil's economic downturn that was already happening before the COVID-I9 pandemic hit the country (Friedman, 2020). Similar to Trump, we argued that Bolsonaro also creates a rhetoric of 'us versus them,' which is people versus the elites. We suggested that his denial of the mainstream media reports about Brazil's health crisis (Brum, 202I) indicates such a communication strategy. Bolsonaro also put his political opponents in this 'us versus them' context. He accused them tried to destroy Brazil because they support more stringent measures in dealing with the COVID-I9 pandemic (Lasco, 2020).

Nevertheless, in 202I, Bolsonaro has had a change of attitude and approach toward the pandemic. He started to speed up the process of vaccine procurement in Brazil. Analysts have suggested that this rebranding effort might be related to Bolsonaro's political interest (Coletta et al., 202I; Nugent, 202I). The business community in Brazil has been growing some pressure on Bolsonaro to address the worsening pandemic situation actively. Furthermore, Bolsonaro may also face a tough political challenge in the future from his political opponents, as Luiz Inacio Lula da Silva would be free to compete against Bolsonaro in the 2022 presidential election. Lula is a famous leftist who did not join the 2018 presidential election due to corruption charges. He had been cleared from the charges by Brazil's supreme court.

In Indonesia, the first official COVID-I9 cases were announced in March 2020. Since then, we argue that the progress of how the Indonesian government under President Joko Widodo, or known as Jokowi, has handled the pandemic indicates some similarities with the US and Brazil situation. First, there is no clear communication strategy in handling the pandemic, which in mostly of the cases, indicates the lack of coordination within the government itself. Such a situation could be seen clearly, one of which, ahead of the 202I Eid Holiday (Hakim, 202I). Transportation Minister Budi Karya Sumadi said that the government did not forbid people from homecoming during the holiday. On the other hand,
National COVID-i9 Task Force Spokesperson Wiku Adisasmito said that the government had not yet decided anything whether there should be some restriction for the homecoming or not.

During the initial phase, statements from government officials primarily also undermined the gravity of the impact that the pandemic may cause, despite many countries have started to suffer from the impact of the COVID-I9 pandemic (Bland, 2020). Jokowi also plays 'the economic crisis' card, the rhetoric of 'us versus them.' He argued that the impact of stringent measures to control the pandemic would have a massive negative impact on the economic and social sectors (Wicaksono, 2020). As a result, the government tried to downplay the public health issues relating to the COVID-I9.

However, compared to the other two countries, Indonesia's situation is a bit more complex, particularly involving the health sector's readiness in facing a pandemic and issues surrounding data transparency related to the pandemic. Adding to the complexity are the characteristics of Indonesia as communal community with all its traditions, myths, and values. For example, there were assumptions in certain communities that COVID-I9 is a demon, hence it needs to be expelled with mystical efforts. Moreover, a study found that the Indonesian government's transparency related to COVID-I9 issues is somewhat at a low point (Pramiyanti et al., 2020). The newly appointed Health Minister Budi Gunadi Sadikin, who replaced the problematic minister Terawan Agus Putranto, even stated that he would not use the Health Ministry's data regarding COVID-I9 cases (VOI, 202I).

\section{The Timeline Comparison of Crisis Communication}

In order to fulfil the aims of the study which is to explore how the crisis communication are conducted in the three respective democratic governments, we compare the communication timeline between Brazil, Indonesia, and the United States. The communication itself were directed by the head of governments 
which is the president, some of them from the Ministers in the form of speech or observation towards news in the mass media (See table I, 2, 3 in Appendix).

\section{Public Efforts in Responding the Governments' Crisis Communication: A Grassroot Initiative in Democratic Countries}

Reflecting from the failure of the government in handling the pandemic and delivering an effective crisis communication, it is important then to look at the role of public in fulfilling the gap that was left by the government. One of the roles that can be taken by the public is to become an open government data intermediary. While it is true that the government has already collected the public health data, the problem lies in how they are communicating those data to give a sound and comprehensive understanding to its citizen. The public with each of their skills and abilities can help the government to formulate a better policy and building a transformative capacity building from grassroots level.

There are some good public initiatives which demonstrate the importance of open government data intermediaries. KawalCOVIDig and Pandemic Talks are two among of many popular public initiatives that happened in Indonesia during this COVID-I9 crisis. KawalCOVIDig was launched by some volunteers that have concerns over the confusion of information circulating in Indonesia regarding COVID-I9. The volunteers consist of pro-data Indonesian netizens that comes from various background; medical, education, science, research, technology, and mass communication. They are doing this initiative first by curating and analyzing information circulated in the media and put forward only evidence based information, not opinions or hypothesis. The verification process of how they provide information is done with collaborating with other public initiatives called Indonesian Anti Slander and Hoax Society (Mafindo) (KawalCOVIDi9, 2020). The media that they choose to use are by using kawalcovidig.id as their website and Facebook, Instagram, and Twitter as their social media handle.
As for Pandemic Talks, it was created by three individuals that feels anxious with the pandemic situation in Indonesia. Three of these individuals are coming from different backgrounds; Muhammad Kamil is a doctor, Firdza Radiany is a data analyst, and Mutiara Anissa is a molecular biology lecturer. They see one of the big problems in Indonesia is the information gap, thus they created an Instagram account with a goal to compile and provide official data related to COVID-I9 pandemic in a simple, yet blunt way. The contents they provide are mostly by 'repackaging' and presenting it in an appealing graphic. Besides, they also created their content through podcasts by discussing certain issues related to COVID-I9 by inviting relevant guests.

Both of those public initiatives have gained some traction, both in a positive manner and in a negative sentiment. Some of the public appreciate their efforts in playing the role as an open government data intermediary, it is reflected by the high number of followers, likes, and engagements on each of their own platforms. Although others have also pointed its fingers towards them by saying the way they communicate to public only creates more fear rather than make the public calmer in enduring this crisis (Maharani, 2020). As an intermediary, dr. Kamil also acknowledge their limitation of not being a professional investigator or journalist and even Pandemic Talk's goal is not aimed to change or correcting the government's policy. However, what we can learn from both KawalCOVID-I9 and Pandemic Talk is that at least by doing this data activism, they already creating a room of public discussion and leading it into a development of critical consciousness.

The story of the role of open data government intermediaries in Indonesia is only one prove on how the public can help the government in handling the communication aspect in pandemic situation. We can also learn from other initiative that is organized by Catalytic Communities (CatComm) that aimed to help one of the most vulnerable communities (favela) in Brazil during this COVID-I9 pandemic. Together with Esri, they built The COVID-I9 In Favelas Unified Dashboard in July 2020. Since then, the Dashboard has become a pri- 
mary reference for community groups, media outlets, public agencies, and researchers (Catalytic Communities, 2020). They get the data not only from public data sources (e.g. clinics, municipal dashboard and zip code-based data), but also community NGO-collected data and from local rapporteurs undertaking counting efforts (Catalytic Communities, 2020). With this kind of initiative model, we can learn the importance of collaborative efforts among the layers of public itself and how they focus on the favela as one of the most vulnerable community during a pandemic.

From the United States, one thing we can learn is how big and important is the power from technology/media company when they step up against misinformation during the pandemic. On March I7, 2020 Facebook, Google, LinkedIn, Microsoft, Reddit, Twitter, and YouTube issued a joint statement declaring their commitment in combating fraud and misinformation related to COVID-I9 (Vidon, 2020). Some of the measures in dealing with this top-down spread of misinformation is by implementing fact-checker on their platform, content or post removal from President Trump and President Bolsonaro social media account, and ultimately permanent suspension on President Trump Twitter account on January 8, 202I (Twitter Inc., 202I). On the other side, some would argue that these kind of actions taken by technology or media company is a threat to free speech. However, what we can learn from this story from the United States is non-government actors could also help build pressure towards government that is not transparent and performed poorly in communicating with public during a crisis.

\section{CONCLUSION}

This study aimed to provide the comparison of the crisis communication practices of three respective democratic governments which cover Brazil, Indonesia, and the United States. From the study that has been conducted, there are at least four main factors that could hinder the effectiveness of crisis communication. First, is huge population and politically divide in the society. Second, is the lack of coordi- nation between levels of governments. Third, governments' lack of capability to communicate with the public and fourth, the incompetency of crisis communication strategy.

During the COVID-I9 pandemic conducted by the three governments, it acknowledges the nuance of incompetency of public communication by the head of governments as well as the ministers. The dissatisfaction of the public with the communication made by the government has led to the emergence of many grassroots initiatives. This is to balance the communications implemented by the government. In fact, by this grassroots effort in making the alternative channels to disseminate information to the public has made the people well informed about the essential matters related to the handling of the pandemic, particularly related to the data transparency and public health promotion.

In the times of crisis, we cannot rely and just hope that the crisis will resolve itself on the hands of the government. Public effort in the form of grassroot initiative is required to ensure the government transparency and help to fulfill their responsibility for its citizen. On the case of public participation initiatives in Indonesia, Brazil, and the United States, the open government data intermediaries have the ability to build public critical awareness by providing an easier to understand information related to pandemic while also pressuring the government to ensure its governance transparency by doing acts related to data activism. The differences in terms of their types of intermediaries, being it an activist, journalist, or hackers, it can only lead to a more comprehensive and effective collaboration in tackling this COVID-I9 pandemic.

The effectiveness of one country in handling the crisis is determined by the quality of crisis communication. The quality of governments' communication could be evaluated through the assessment of crisis communication, one of the examples is through ACCP's assessment tool. However, this study only looked at its six domains without going deeper to the items from each domain. Thus, further research is still needed to enrich the study particularly in related to the specific issue such as 
political divide in a democratic country with huge population.

\section{REFERENCES}

Akhli, R. A., \& Samhudi, G. R. (2020). Kepentingan Politik Donald Trum dan Xi Jinping dalam Meningkatkan Relasi Konfliktual antara AS-Tiongkok di Masa Pandemi COVID-I9. Jurnal Penelitian Politik, I7(2), 235-253. https://doi. org/IO.I4203/jpp.vi7i2.887

Altakarli, N. S. (2020). China's Response to the COVID-I9 Outbreak: A Model for Epidemic Preparedness and Management. Dubai Medical Journal, 3(2), 44-49. https://doi. org/IO.II59/000508448

Annaka, S. (202I). The Truth and Myth of the Advantages of Authoritarian Countries to COVID-I9. APSA Preprints, I-22.

Baleta, A. (2007). Forced isolation of tuberculosis patients in South Africa. The Lancet Infectious Diseases, 7(I2), 771. https://doi.org/Io.IoI6/sI4733099(07)7028I-5

BBC. (2020, April 2I). Coronavirus lockdown protest: What's behind the US demonstrations? BBC. https://www.bbc. com/news/world-us-canada-5235910o

BBC. (2020, March I9). Coronavirus protest in Brazil sees millions bang pots from balconies. Retrieved from BBC: https:// www.bbc.com/news/world-latinamerica-51955679

BBC. (202I, March 3I). Brazil: Political Crisis and COVID surge rock Bolsonaro. BBC. https://www.bbc.com/news/world-latinamerica-5658II3I

Bland, B. (2020, March I7). Indonesia: COVID-I9 crisis reveals cracks in Jokowi's ad hoc politics. The Interpreter. https:// www.lowyinstitute.org/the-interpreter/ indonesia-COVID-I9-crisis-revealscracksjokowi-s-ad-hoc-politics
Brum, E. (202I, January 29). Study finds that Brazil's Jair Bolsonaro carried out an 'institutional strategy to spread the coronavirus.' El Pais. https://english. elpais.com/americas/202I-OI-29/studyfinds-that-brazils-jair-bolsonarocarriedout-an-institutional-strategy-to-spreadthe-coronavirus.html

Catalytic Communities. (2020, July 7). COVID-I9 in Favelas Unified Dashboard Launched. Retrieved from Catcomm.org: https://catcomm.org/covid-dashboardrelease-oI/

Cepaluni, G., Dorsch, M., \& and Branyiczki, R. (2020, April 27). Political Regimes and Deaths in the Early Stages of the COVID-I9 Pandemic. APSA Preprints. doi:doi.org/Io.33774/apsa-2020-5lhhc

Cheng, Y. \& Lee, C. J. (2019). Online crisis communication in a post-truth Chinese society: Evidence from interdisciplinary literature. Public Relations Review, 45(4), IoI826. Doi:Io.IoI6/j.pubrev.20I9.IoI826

Coletta, R. Della, Uribe, G., \& Carvalho, D. (202I, March II). Sob influência de filho e aliados, Bolsonaro adapta discurso para evitar perda de apoio de empresários. Folha deS.Paulo. https://wwwi.folha.uol. com.br/poder/202I/03/sob-influenciade-filho-bolsonaro-adapt a-discurso-nacovid-para-evitar-perda-de-apoio-deempresarios.shtml

Dempere, J. (202I). A recipe to control the first wave of COVID-I9: More or less democracy? Transforming Government: People, Process and Policy. https://doi. org/Io.IIo8/TG-08-2020-0206

Detik. (2020, September 2). Timeline Setengah Tahun COVID-I9 di Indonesia. Detik.Com. https://news.detik.com/ berita/d-5I56I99/timeline-setengahtahun-COVID-I9-di-indonesi a?single=I

Eberl, J., Huber, R. A., \& Greussing, E. (202I). From Populism to the ' Plandemic ': Why populists believe in COVID-I9 conspiracies. Journal of Elections, Public Opinion and Parties, 3I(I), 272-284. https:// doi.org/Io.Io80/I7457289.202I.I924730 
Eugene Kiely; Lori Robertson; Rem Rieder; D'Angelo Gore. (2020). Timeline of Trump's COVID-I9 Comments. Factcheck.Org. https://www.factcheck. org/2020/ro/timeline-of-trumpsCOVID-I9-comments/

Evanega, S., Lynas, M., Adams, J., \& and Smolenyak, K. (2020). Quantifying sources and themes in the COVID-I9 'infodemic'. COVID-ro 'infodemic' study. Retrieved from https:// allianceforscience.cornell.edu/wpcontent/uploads/2020/o9/Evanega-etal-Coronavirus-misinformationFINAL. pdf

Farzan, A. N., \& Berger, M. (2020, November II). Bolsonaro says Brazillians must not be 'sissies' about coronavirus, as 'all of us are going to die one day'. Retrieved from The Washington Post: https://www. washingtonpost.com/world/2020/II/II/ bolsonaro-coronavirus-brazil-quotes/

Feufel, M. A., Antes, G., \& Gigerenzer, G. (2010). [Competence in dealing with uncertainty: lessons to learn from the influenza pandemic ( $\mathrm{HINI}$ ) 2009]. Bundesgesundheitsblatt, Gesundheitsforschung, Gesundheitsschutz, 53(I2), I283-I289. https://doi.org/Io.IO07/ SOOIO3-OIO-II65-I

Friedman, U. (2020, March 28). The Coronavirus-Denial Movement Now Has a Leader. The Atlantic. https:// www.theatlantic.com/politics/ archive/2020/03/bolsonaro-coronavirusdenial-bra zil-trump/6o8926/

Gallup. (202I). Presidential Approval Ratings -- Donald Trump. Gallup. https://news. gallup.com/poll/203I98/presidentialapproval-ratings-donald-trump.aspx

Hakim, R. N. (2020, September 2). Kilas Balik 6 Bulan COVID-I9: Pernyataan Kontroversial Pejabat soal Virus Corona. Kompas.Com. https://nasional.kompas. $\mathrm{com} / \mathrm{read} / 2020 / 09 / 02 / 09285 \mathrm{III} /$ kilas-balik-6-bulan-COVID-I 9pernyataan-kontroversial-pejabat-soalvirus?page $=$ all
Hakim, R. N. (202I, March I6). Beda dengan Menhub, Satgas COVID-I9 Sebut Kebijakan Terkait Mudik Lebaran Masih Dibahas Pemerintah. Kompas. Com. https://nasional.kompas.com/ $\mathrm{read} / 202 \mathrm{I} / 03 / \mathrm{I} 6 / 2259347 \mathrm{I} /$ beda-denganmenhub-satgas-COVID-I9-sebutkebijakan-terkait-mudik-lebaran

Halim, D. (2020, October 20). Survei Litbang Kompas Setahun JokowiMa'ruf: 52,5 Persen Tak Puas, 45,2 Persen Puas. Retrieved from Kompas. com: https://nasional.kompas.com/ $\mathrm{read} / 2020 / \mathrm{IO} / 20 / \mathrm{I35253II/survei-litbang-}$ kompas-setahun-jokowi-maruf-525persen-tak-puas-452-persen?page $=$ all

Hatcher, W. (2020). A Failure of Political Communication Not a Failure of Bureaucracy: The Danger of Presidential Misinformation During the COVID-I9 Pandemic. The American Review of Public Administration, 50(6-7), 614-620.

Her, M. (2020). How Is COVID-I9 Affecting South Korea? What Is Our Current Strategy?. Disaster Medicine and Public Health Preparedness, I4(5), 684-686. https://doi.org/Io.IOI7/dmp.2020.69

Jong, W. (202I). Evaluating Crisis Communication: A 30-item Checklist for Assessing Performance during COVID-I9 and Other Pandemics. Journal of Health Communication. doi:I0.1080/1080730.20 2I.I87I79I

Kavanagh, M. M., \& Singh, R. (2020). Democracy, capacity, and coercion in pandemic response: COVID-I9 in comparative political perspective. Journal of Health Politics, Policy and Law, 45(6), 997-IoI2. https://doi. org/10.I215/03616878-8641530

KawalCOVIDi9. (2020). Tentang Kami. Retrieved from https://kawalcovidis.id/: https://kawalcovidı.id/tentang-kami

Knoll, J.H. (I979). The Importance and use of comparative studies in adult education in the framework of academic courses of study. I979 Conference Proceedings (pp. 6-I6). United Kingdom: Leeds University. 
Kuguyo, O., Kengne, A. P., \& Dandara, C. (2020). Singapore COVID-I9 Pandemic Response as a Successful Model Framework for Low-Resource Health Care Settings in Africa? OMICS A Journal of Integrative Biology, 24(8), 470-478. https://doi.org/ro.I089/omi.2020.0077

Kusuma, H. (2020, October 2). Perputaran Uang Selama Pilkada Diprediksi Tembus Rp 26 T. Retrieved from detikfinance: https://finance.detik.com/beritaekonomi-bisnis/d-5197908/perputaranuang-selama-pilkada-diprediksitembus-rp-26-t

Lasco, G. (2020). Medical populism and the COVID-I9 pandemic. Global Public Health, I5(I0), I4I7-I429). https://doi.org /I0.I080/I744I692.2020.180758I

Lee, Y. N. (2020, March II). Global coronavirus outbreak has 'exploded' and the aftermath could last a year, Singapore's foreign minister says. Retrieved from CNBC: https://www.cnbc.com/2020/03/II/ coronavirus-economic-impact-couldlast-a-year-singapore-foreign-minister. html

Magalhaes, G., Roseira, C., \& Strover, S. (2013). Open Government Data Intermediaries: A Terminology Framework. ICEGOV 'I3: Proceedings of the 7 th International Conference on Theory and Practice of Electronic Governance (pp. 330333). Seoul: Association for Computing Machinery.

Maharani, A. (2020, September 25). Masalah Terbesar Pandemi adalah Gap Informasi. Retrieved from Klik Dokter: https:// www.klikdokter.com/info-sehat/ $\mathrm{read} / 3644429 / \mathrm{masalah}$-terbesarpandemi-adalah-gap-informasi

Meng, A., \& DiSalvo, C. (2018). Grassroots resource mobilization through counterdata action. Big Data \& Society, 5(2), I-I2.

Navarro, J. A., \& Markel, H. (20I6). About. In Influenza Encyclopedia. the University of Michigan Center for the History of Medicine and Michigan Publishing. https://www.influenzaarchive.org/ about.html

Nugent, C. (202I, March I2). Brazil's Bolsonaro Denied COVID-I9 Was a Problem. Now He's Embracing Vaccines. Here's What Changed. Time. https://time. com/594640 I/brazil-COVID-I9vaccines-bolsonaro/

Pramiyanti, A., Mayangsari, I. D., Nuraeni, R., \& Firdaus, Y. D. (2020). Public perception on transparency and trust in government information released during the COVID-I9 pandemic. Asian Journal for Public Opinion Research, 8(3), 35I-376. https://doi.org/Io.I5206/ ajpor.2020.8.3.35I

Reuterss. (2020, July 8). Timeline: Key moments in Bolsonaro's handling of COVID-I9 crisis. Reuters. https://www.reuters. com/article/uk-health-coronavirusbrazil-timeline-idAFKBN2482 UP

Riley, R. (2020). A Review of the Impacts of the I9I8 Spanish Flu Pandemic. University of Birmingham. https://blog.bham.ac.uk/ cityredi/a-review-of-the-impacts-of-theI9I8-spanish-flu-pandemic/

Rosenwald, M. S. (202I, February 22). History's deadliest pandemics, from ancient Rome to modern America. The Washington Post. https://www.washingtonpost. com/graphics/2020/local/retropolis/ coronavirus-deadliestpandemics

Rowland, R. C. (20I9). The populist and nationalist roots of Trump's rhetoric. Rhetoric and Public Affairs, 22(3), 343-388. https://doi.org/IO.I432I/ rhetpublaffa.22.3.0343

Scrock, A., \& Shaffer, G. (20I7). Data ideologies of an interested public: A study of grassroots open government data intermediaries. Big Data \& Society, 4(I), I-IO.

Sebhatu, A., Wennberg, K., Arora-Jonsson, S., \& Lindberg, S. I. (2020). Explaining the homogeneous diffusion of COVID-I9 nonpharmaceutical interventions across heterogeneous countries. Proceedings of the National Academy of Sciences of the United States of America, II7(35), 
2I2OI-2I208. https://doi.org/I0.IO73/ pnas.2010625II7

Sevastopulo, D., \& Shubber, K. (2020, April 20). Trump cheers as anti-lockdown protests spread. Financial Times. https://www. ft.com/content/c8f6f4I3-39c4-47ce-biffoe02969cb6I2

Siegrist, M., \& Cvetkovich, G. (2000). Perception of hazards: The role of social trust and knowledge. Risk Analysis, 20(5), 713-720. https://doi.org/IO.IIII/02724332.205064

Siegrist, M., \& Zingg, A. (20I4). The role of public trust during pandemics: Implications for crisis communication. European Psychologist, I9(I), 23-32. https://doi.org/IO.IO27/IOI6-9040/ aoooi69

Smith, D. (2020, April 4). "I'm not going to do it": Trump rejects his own administration's advice on masks. The Guardian. https:// www.theguardian.com/world/2020/ apr/o3/im-not-going-to-do-it-trumprefutes-his-own-administrations-adviceon-masks

Stern., A M, \& Cetron, M, \& Markel, H. (2010). The I9I8-I9I9 Influenza Pandemic in the United States: Lesson Learned and Challenges Exposed. Public Health Rep, $\quad$ I25 (Suppl 3): 6-8. https://doi. org/Io.II77/0033354910I250\$303

The New York Times. (20I7, August 9). 2016 Presidential Election Results. The New York Times. https://www.nytimes.com/ elections/2016/results/president

Twitter Inc. (202I, January 8). Permanent suspension of @realDonaldTrump. Retrieved from blog.twitter.com: https://blog.twitter.com/en_us/topics/ company/2020/suspension.html

Valerisha, A., \& Putra, M. A. (2020). Pandemi Global COVID-I9 dan Problematika Negara-Bangsa: Transparansi Data Sebagai Vaksin Socio-Digital? Jurnal Ilmiah Hubungan Internasional, I3II37. https://doi.org/Io.26593/jihi. voio.387I.I3I-I37
Vidon, T. S. (2020, April 26). Conspiracy theories and fake news: Fighting the COVID-I9 'infodemic'. Retrieved from France 24: https://www.france24.com/ en/20200426-conspiracy-theories-andfake-news-fighting-the-COVID-I9infodemic

VOI. (202I, January 22). Minister Of Health Budi Gunadi: I Give Up Using Data From The Ministry Of Health. VOI. https://voi.id/en/berita/28332/menkesbudi-gunadi-saya-kapok-pakai-datakemenkes

WHO. (2020). WHO Coronavirus (COVID-I9) Dashboard. June 3rd. Retrieved from WHO (COVID-I9): https://covidı9.who. int/

Wicaksono, R. M. T.A. D. (2020). Examining the Policies and Priorities of the Indonesian Government in Response to COVID-I9. LIPI. http://www.politik.lipi.go.id/ kolom/kolom-2/politik-nasional/I4Ioexamining-the-policie s-and-prioritiesof-the-indonesian-government-inresponse-to-COVID-I9

Yamey, G., \& Gonsalves, G. (2020). Donald Trump: a political determinant of COVID-I9. The BMJ. https://doi.org/ https://doi.org/Io.II36/bmj.mi643 


\section{AUTHOR BIOGRAPHIES}

Marshell Adi Putra is a researcher and lecturer at the Department of International Relations, Parahyangan Catholic University, Bandung. Marshell earned his master's degree in Intercultural and International Communication from the American University, Washington, DC and his bachelor's degree in International Relations from Parahyangan Catholic University, Bandung. His research interests are in public diplomacy, media studies, and the relationship between society and technology.

Ignasius Loyola Adhi Bhaskara is a lecturer at the Parahyangan Catholic University in Bandung, Indonesia. He received his master's degree from the University of Sydney, majoring in Peace and Conflict Studies, and got his bachelor's degree from the International Relations Department at Gadjah Mada University, Yogyakarta. His research interest is in the area of conflict and media studies.

Anggia Valerisha is a lecturer at the Department of International Relations, Faculty of Social and Political Sciences, Parahyangan Catholic University (UNPAR), Bandung. She got her BA. (Bachelor of Arts) from the Department of IR UNPAR and continues to study for her Master's Degree in Social Science at UNPAR. She is interested in transnational issues, especially on the topic of media politics and gender. She is actively involved in various research projects and community services. Some of her publications are: "The Impact of Media Conglomeration Practices in Achieving Consolidated Democracy in Indonesia" (2016), "The COVID-I9 Global Pandemic and the Problems of the Nation-States: Data Transparency as a Socio-Digital Vaccine?" (2020), "IKEA in Indonesia: The Synergy of Swedish Public Diplomacy and Nation Branding" (2020), "Behind the Ulap Doyo of East Borneo: Indigenous Women and the Importance of Media Coverage" (2020), and "Examining Public Relations Communication in Indonesia's Digital Diplomacy” (202I). (Google Scholar: Anggia Valerisha) 


\section{APPENDIX I}

Table I. Crisis communication timeline in Brazil

\begin{tabular}{|c|c|}
\hline Date/Year of 2020 & Events \\
\hline 26 February & Brazil confirms first coronavirus case. \\
\hline March I2 & $\begin{array}{l}\text { Brazil's presidential communications secretary tests positive for COVID-I9 after returning } \\
\text { from Florida. He and Bolsonaro met with Trump there }\end{array}$ \\
\hline March I3 & Bolsonaro says he tested negative \\
\hline March I5 & $\begin{array}{l}\text { Ignoring medical advice to quarantine, Bolsonaro takes selfies with supporters at a rally in } \\
\text { Brasilia. }\end{array}$ \\
\hline March 20 & $\begin{array}{l}\text { Health Minister Luiz Henrique Mandetta says the virus poses an existential threat to } \\
\text { Brazil's fragile healthcare system, which could start to collapse in April. }\end{array}$ \\
\hline March 24 & $\begin{array}{l}\text { Bolsonaro urges mayors and state governors to roll back lockdown measures in a televised } \\
\text { national address. }\end{array}$ \\
\hline April I6 & Bolsonaro fires Mandetta. He had clashed with Mandetta over social distancing measures. \\
\hline May I2 & $\begin{array}{l}\text { Brazil's confirmed coronavirus cases total passes Germany. Bolsonaro tries to reopen gyms } \\
\text { and beauty parlors by presidential decree. }\end{array}$ \\
\hline May I5 & $\begin{array}{l}\text { Bolsonaro loses his second health minister in less than a month after Nelson Teich resigns } \\
\text { due to differences over the use of antimalarial drugs in treating COVID-I9. }\end{array}$ \\
\hline May 20 & $\begin{array}{l}\text { The Health Ministry, led by an active-duty army general on an interim basis, issues new } \\
\text { guidelines for wider use of unproven antimalarial drugs in mild coronavirus cases. }\end{array}$ \\
\hline May 24 & The US limits travel from Brazil amid worsening coronavirus outbreak. \\
\hline June 6 & $\begin{array}{l}\text { Brazil removes from public view months of data on its COVID-I9 epidemic. Bolsonaro on } \\
\text { Twitter: "The cumulative data ... does not reflect the moment the country is in." }\end{array}$ \\
\hline June 9 & Brazil restores the data following a Supreme Court ruling. \\
\hline June 9 & Brazil restores the data following a Supreme Court ruling. \\
\hline June 23 & $\begin{array}{l}\text { A judge orders Bolsonaro to wear a mask in public after he attended political rallies without } \\
\text { one. }\end{array}$ \\
\hline July 7 & Bolsonaro says he has tested positive. \\
\hline
\end{tabular}

Source: Reuters, 2020

Table 2. Crisis communication timeline in Brazil

\begin{tabular}{ll}
\hline Date/Year of 2020 & Events \\
\hline February 25 & $\begin{array}{l}\text { The government disbursed Rp72 billion to pay influencers and media promotion to } \\
\text { promote tourism as the sector was heavily impacted as the COVID-I9 hit the world. }\end{array}$ \\
\hline March 2 & $\begin{array}{l}\text { First positive cases announced. Health Minister Terawan said that the death rate of flu was } \\
\text { much higher than COVID-I9. }\end{array}$ \\
\hline March II & First death cases. WHO announced COVID-I9 as a pandemic. \\
\hline March I2 & $\begin{array}{l}\text { Health Minister Terawan said people who got COVID-I9 will heal eventually as COVID-I9 } \\
\text { isa a self limiting disease }\end{array}$ \\
\hline March I3 & Jokowi established COVID-I9 Task Force. \\
\hline March 20 & Jokowi ordered Avigan and hydroxychloroquine. \\
\hline March 3I & Jokowi announced a public health emergency situation. He issued a Large-Scale Social \\
\hline April 6 & Restrictions (PSBB) policy. \\
\hline April I3 & Jokowi developed COVID-I9 specialized hospital in Galang Island \\
\hline April 22 & Jokowi announced COVID-I9 as a national disaster. \\
\hline May 7 & Jokowi did not forbid people for homecoming during Eid. \\
\hline
\end{tabular}




\begin{tabular}{ll}
\hline May I8 & Jokowi announced restrictions on homecoming activities during Eid. \\
\hline May 30 & $\begin{array}{l}\text { Jokowi said there were I4 thousands people who did homecoming. The number does not } \\
\text { include people who use private vehicles }\end{array}$ \\
\hline July 3 & $\begin{array}{l}\text { The Agriculture Ministry released an "antivirus necklace" that was claimed to be able to kill } \\
\text { novel coronavirus }\end{array}$ \\
\hline September I & $\begin{array}{l}\text { Jokowi says the virus is under control. "If we compared to other countries, Indonesia is } \\
\text { relatively in control," says Jokowi }\end{array}$ \\
\hline
\end{tabular}

Source: Detik, 2020; Hakim, 2020

Table 3. Crisis Communication Timeline in the United States

\begin{tabular}{|c|c|}
\hline Date/Year of 2020 & Events \\
\hline January 20 & Coronavirus detected in the US \\
\hline January 30 & $\begin{array}{l}\text { Trump speech in Michigan: "We think we have it very well under control. We have very } \\
\text { little problem in this country at this moment ... But we're working very closely with China } \\
\text { and other countries, and we thinking it's going to have a very good ending for us. }\end{array}$ \\
\hline January $3 \mathrm{I}$ & The US Department of Health and Human Services declares a public health emergency \\
\hline February 7 & $\begin{array}{l}\text { Trump interview with Bob Woodward: "It goes through air, Bob ... It's also more deadly } \\
\text { than your, you know, your even your strenuous flus." }\end{array}$ \\
\hline February io & $\begin{array}{l}\text { Trump at the White House: Now, the virus that we're talking about having to do, you know, } \\
\text { a lot of people think that goes away in April with the heat ... We're in great shape though. }\end{array}$ \\
\hline February 26 & $\begin{array}{l}\text { Trump at the White House: "I want you to understand something that shocked me when I } \\
\text { swa that, and I spoke with Dr. Fauci on this ... and I think most people are amazed to hear } \\
\text { it: The flu, in our country, kills from } 25,000 \text { people to } 69,000 \text { people a year ... and, so far, } \\
\text { if you look at what we have with the I5 people and their recovery, one is pretty sick but } \\
\text { hopefully will recover, but other are in great shape. }\end{array}$ \\
\hline February 27 & $\begin{array}{l}\text { Trump at the White House: "It's going to disappear. One day, it's like a miracle, it will } \\
\text { disappear. }\end{array}$ \\
\hline March II & The WHO declares the COVID-I9 as pandemic. \\
\hline March I3 & Trump declares a national emergency. \\
\hline March i9 & $\begin{array}{l}\text { Trump interview with Woodward: "To be honest with you, I wanted to always play it down } \\
\text {... I don't want to create a panic." }\end{array}$ \\
\hline March 23 & $\begin{array}{l}\text { Trump at a White House task force briefing: "People get tremendous, anxiety and } \\
\text { depression, and you have suicides over things like this when you have terrible economies. } \\
\text { You have death." }\end{array}$ \\
\hline \multirow[t]{2}{*}{ March 24} & $\begin{array}{l}\text { Trump interview on Fox News: "So I think Easter Sunday and you'll have packed churches } \\
\text { all over our country." }\end{array}$ \\
\hline & $\begin{array}{l}\text { "And actually this year we're having a bad flu season, but we lose thousands of people a } \\
\text { year to the flu. We never turn the country off. We lose much more than that to automobile } \\
\text { accidents." }\end{array}$ \\
\hline \multirow[t]{2}{*}{ March 30} & - The White House extends "slow the spread" recommendations. \\
\hline & $\begin{array}{l}\text { - Trump at a White House task force briefing: "I've had many friends, business people } \\
\text { with great, actually common sense, they said, 'Why don't we ride it out?' ... A lot of } \\
\text { people have thought about it, 'Ride it out, don't do anything, just ride it out, and think } \\
\text { of it as the flu. But it's not the flu." }\end{array}$ \\
\hline \multirow[t]{2}{*}{ April 3} & - The CDC recommends that people begin wearing facemask. \\
\hline & $\begin{array}{l}\text { - Trump in a task force press briefing: "So it's voluntary; you don't have to do it. They } \\
\text { suggested for a period of time ... I do not think I'm going to be doing it." }\end{array}$ \\
\hline April 23 & $\begin{array}{l}\text { Trump in a task force press briefing: "And then I see the disinfectant, where it knocks it } \\
\text { out in a minut, one minute. And is there a way we can do something like that by injection } \\
\text { inside or almost a cleaning because you see it gets in the lungs and it does a tremendous } \\
\text { number on the lungs. So it'd be interesting to check that." }\end{array}$ \\
\hline May I8 & $\begin{array}{l}\text { Trump in a roundtable: "I'm taking it, hydroxychloroquine ... right now. Because I think it's } \\
\text { good. I've heard a lot of good stories." }\end{array}$ \\
\hline
\end{tabular}




\begin{tabular}{ll}
\hline May 25 & $\begin{array}{l}\text { Trump's tweet: "Great reviews on our handling of COVID-I9, sometimes referred to as the } \\
\text { China Virus. Ventilators, Testing, Medical Supply Distribution, we made a lot of Governors } \\
\text { look very good and got no credit for so doing." }\end{array}$ \\
\hline June I7 & $\begin{array}{l}\text { Trump's interview with the Wall Street Journal: "I think it's time to start our country up } \\
\text { again, basically. And could we keep it shut longer? Personally, I don't think so." }\end{array}$ \\
\hline June 25 & $\begin{array}{l}\text { Trump in a televised virtual town hous: "So, we have more cases because we do the greatest } \\
\text { testing. If we don't do testing, we'd have no cases ... So we're up to almost 30 million tests. } \\
\text { So when you do } 30 \text { million, you're going to have a kid with the sniffles, and they'll say it's } \\
\text { coronavirus." }\end{array}$ \\
\hline
\end{tabular}

Source: (Eugene Kiely; Lori Robertson; Rem Rieder; D’Angelo Gore, 2020) 